\title{
Abundance and community structure of sulfate reducing prokaryotes in a paddy soil of southern China under different fertilization regimes
}

\author{
Xin-Zhan Liu ${ }^{\text {a,b }}$, Li-Mei Zhang ${ }^{\text {a }}$, James I. Prosser ${ }^{\mathrm{c}}$, Ji-Zheng $\mathrm{He}^{\mathrm{a}, *}$ \\ a State Key Laboratory of Urban and Regional Ecology, Research Center for Eco-Environmental Sciences, Chinese Academy of Sciences, Beijing 100085, China \\ ${ }^{\mathrm{b}}$ Graduate School, Chinese Academy of Sciences, Beijing 100039, China \\ ${ }^{\text {c }}$ School of Biological Sciences, University of Aberdeen, Aberdeen AB24 3UU, Scotland, UK
}

\section{A R T I C L E I N F O}

Article history:

Received 10 August 2008

Received in revised form 10 December 2008

Accepted 6 January 2009

Available online 27 January 2009

\section{Keywords:}

Sulfate reducing prokaryotes

Bacteria

Paddy soil

Fertilization

Clone libraries

Quantification

Real-time PCR

\begin{abstract}
A B S T R A C T
Flooded rice paddy soils represent a typical anaerobic freshwater habitat of microorganisms. The abundance and community structure of sulfate reducing prokaryotes (SRP) were investigated in order to understand their response to different fertilization practices in rice paddy, including control without fertilizers (CT) and arrangements of different chemical fertilizers of nitrogen (N), phosphorus (P) and potassium (K): N, NP, NK and NPK. The abundance of total bacteria and sulfate reducing prokaryotes of the rice paddy in summer and in winter were quantified by real-time PCR assays based on the 16S rRNA gene and the dissimilatory (bi)sulfite reductase gene $(d s r A B) \beta$-subunit. No significant differences in the bacterial and SRP abundance were observed among different fertilization treatments in both winter and summer. The mean copy numbers of bacteria was $7.26 \times 10^{9}$ copies $\mathrm{g}^{-1}$ dry soil in winter and $1.27 \times 10^{10}$ copies $g^{-1}$ dry soil in summer. The average $d s r A B$ gene copy numbers of the SRP was $5.08 \times 10^{8}$ copies $\mathrm{g}^{-1}$ dry soil in winter and $5.92 \times 10^{8}$ copies $\mathrm{g}^{-1}$ dry soil in summer. The dsrAB gene clone libraries of the five fertilization treatments were constructed and their RFLP analysis yielded 22-25 restriction patterns, suggesting a high degree of $d s r A B$ sequence diversity in different fertilization treatments. There was no significant change in the soil SRP community structure among the different fertilization regimes. More than half of the sequences were affiliated with novel branching clusters which were uncultured SRP. Clostridia and Deltaproteobacteria were also found with a high proportion in the clone libraries, while Desulfovibrionaceae was absent. High proportion of novel uncultured SRP implies that they may play important roles in paddy soils and deserve further studies.
\end{abstract}

(C) 2009 Elsevier Ltd. All rights reserved.

\section{Introduction}

Flooding of irrigated rice fields produces anaerobic soil conditions, which represents a typical freshwater habitat for microorganisms in terrestrial ecosystems. The depletion of oxygen in the rice bulk soil after flooding can result in the prevalence of anaerobic microbial functional groups, including nitrate reducers, iron reducers, sulfate reducers and $\mathrm{CH}_{4}$-producing archaea (Achtnich et al., 1995). Though sulfate reduction can be limited by the low concentration of sulfur compounds in freshwater environment, significant sulfate reduction rates have been observed in paddy soil microcosms (Wind and Conrad, 1997). The highest in situ sulfate

\footnotetext{
* Corresponding author at: Research Center for Eco-Environmental Sciences, Chinese Academy of Sciences, 18 Shuangqing Road, Beijing 100085, China Tel.: +8610 6284 9788; fax: +86106292 3563 .

E-mail address: jzhe@rcees.ac.cn (J.-Z. He).
}

reduction rates and SRP (sulfate reducing prokaryotes) abundance are found in or near oxygenated areas, such as upper $0-1 \mathrm{~cm}$ soil layer and in rhizosphere soil. It is proven that SRP prefer to live in these areas where the reduced sulfur compounds can be reoxidized (Ouattara and Jacq, 1992; Wind and Conrad, 1995; Wind et al., 1999).

SRP constitute a diverse group of prokaryotes that contribute to a variety of essential functions in many anaerobic environments including participation in the carbon, sulfur, and mercury cycles (Jorgensen, 1982; Gilmour et al., 1998), and biodegradation of organic pollutant such as cresol and biphenyl (Schibata et al., 2007; Yang et al., 2008). Lots of investigations of freshwater SRP populations have been conducted in fens (Castro et al., 2002; Schmalenberger et al., 2007), estuary sediments (Kondo et al., 2004; Leloup et al., 2005), and paddy soils (Stubner and Meuser, 2000; Scheid and Stuber, 2001; Stubner, 2002, 2004). Most of SRP are difficult to cultivate, and therefore culture-independent methods have been used as a powerful method to assess the abundance and 
diversity of SRP. The final stage of the anaerobic sulfate reduction, reduction of sulfite to sulfide, is catalysed by dissimilatory (bi)sulfite reductase, encoded by the $d s r A B$ gene. This gene is found in all known sulfate reducers, which occur in five bacterial and two archaeal phyla, and is therefore a key functional marker for molecular analysis and detection of SRP (Wagner et al., 1998; Castro et al., 2000). Analysis of $d s r A B$ genes amplified from nucleic acids from hydrothermal basin and mesophilic spring has enabled characterization of SRP diversity and identification of novel SRP (Dhillon et al., 2003; Elshahed et al., 2003). The availability of the $d s r A B$ as a functional gene marker enables the application of culture-independent approaches to provide more comprehensive and reliable characterization of the composition and abundance of SRP communities in paddy soils.

Fertilization represents a common and important management practice of paddy soils in Southern China for maximizing the rice yield. Fertile soil provides essential nutrients for crop growth, and then supports a diverse and active microbial community. Knowledge of the microbial community structure shifts following different management practices such as fertilization can advance our understanding of soil processes and microbial functions (Mäder et al., 2002). Our previous studies have shown that the abundance and community structure of soil bacteria, fungi, and other important microbial groups could change following different fertilization practices (He et al., 2007, 2008; Ge et al., 2008; Shen et al., 2008; Zheng et al., 2008). In this study, we hypothesized that long-term fertilization practices could result in changes in SRP abundance and community structure in the paddy soil and novel SRP could be inspired.

\section{Materials and Methods}

\subsection{Site Description}

The paddy field is located at Taoyuan Long-term Paddy Soil Experimental Station of Chinese Academy of Sciences $\left(28^{\circ} 55^{\prime} 49.8^{\prime \prime} \mathrm{N}, 111^{\circ} 26^{\prime} 25.7^{\prime \prime} \mathrm{E}\right)$, Hunan Province, China. It is a reddish clayey paddy soil at an altitude of $89 \mathrm{~m}$, annual rainfall of $1447.9 \mathrm{~mm}$ and mean temperature of $16.5^{\circ} \mathrm{C}$. The long-term fertilization experiment was established in 1990, including three replicates of five treatments in a random plot design as follows: control without fertilizers (CT), chemical fertilizer nitrogen $(\mathrm{N}), \mathrm{N}$ and phosphorus (NP), N and potassium (NK) and NPK. Each plot has an area of $33 \mathrm{~m}^{2}$ and was supplied with $1.35 \mathrm{~kg}$ urea, $2.5 \mathrm{~kg}$ superphosphate and $1.32 \mathrm{~kg}$ potassium chloride annually as $\mathrm{N}, \mathrm{P}$ or $\mathrm{K}$ fertilizers or their combinations. All N, P and $\mathrm{K}$ fertilizers were used as basal fertilizers, whereas $\mathrm{N}$ fertilizer (urea) was used both as a basal and a supplementary fertilizer. Rice-rice rotation was employed in the Station, in which the first crop season was from April to July and the second from July to October.

\subsection{Sample Collection}

Soil samples were taken in winter (January, 2006), when the soil was fallow and waterlogged, and summer (July, 2006), when the soil was planted with rice and waterlogged. Five cores $(5 \mathrm{~cm}$ in diameter) were collected from the top $20 \mathrm{~cm}$ of paddy soil in each replicate plot. Cores were mixed well, pooled in a sterile plastic bag and transported to the laboratory on ice. All the samples were sectioned into two subsamples: one was stored anaerobically at $4{ }^{\circ} \mathrm{C}$ for analysis of soil characteristics; the other was frozen at $-80^{\circ} \mathrm{C}$ for subsequent DNA extraction and molecular analysis.

\subsection{Chemical Analysis}

Soil $\mathrm{pH}$ was determined with $\mathrm{pH}$ meter at a soil to water ratio of 2:5. Soil organic matter was measured using the $\mathrm{K}_{2} \mathrm{Cr}_{2} \mathrm{O}_{7}$ oxidation-reduction titration method (Walkley and Black, 1934). Sulfate concentration was measured by anion exchange chromatography equipped with an AS14 column and an ECD50 conductivity detector (Dionex, USA). The eluent was prepared by mixing $1.8 \mathrm{mM} \mathrm{Na}_{2} \mathrm{CO}_{3}$ and $1.7 \mathrm{mM} \mathrm{NaHCO}_{3}$ with isocratic flow at $1.2 \mathrm{ml} \mathrm{min}^{-1}$. The values were calculated from three triplicates of five fertilization treatments and statistically analyzed using one-way analysis of variance (ANOVA). Selected soil chemical properties are listed in Table 1.

\subsection{Soil DNA Extraction}

DNA was extracted from $0.5 \mathrm{~g}$ of fresh paddy soil using UltraClean $^{\mathrm{TM}}$ Soil DNA Isolation Kits (MoBio Laboratory, USA). The extracted DNA was evaluated on a 1\% agarose gel and the concentration and purity of the extracts were estimated by spectrophotometry (NanoDrop, USA).

\subsection{Quantification of $16 S$ rRNA and dsrAB Genes by Real-Time PCR Assays}

Abundances of bacteria and SRP were determined by quantitative real-time PCR analysis of $16 \mathrm{~S}$ rRNA gene and $d s r A B$ gene $\beta$ subunit, respectively, on an iCycler iQ5 thermocycler (Bio-Rad, USA). Total bacteria were quantified by Taqman assays using the primers BACT1369FB (5'-CGGTGAATACGTTCYCGG-3'), PROK1492R (5'-GGWTACCTTGTTACGACTT-3'), and the probe TM1389F (5'CTTGTACACACCGCCCGTC-3') described by Suzuki et al. (2000). The 25- $\mu$ l reaction mixture included Premix Ex Taq ${ }^{\mathrm{TM}}$ (Takara Biotechnology, Japan), $1 \mu \mathrm{l}$ of BSA, $0.5 \mu \mathrm{l}$ of each primer $(10 \mu \mathrm{M})$ and $2 \mu \mathrm{l}$ of 50-fold diluted extracted DNA (1-5 ng) as template. Quantitative PCR was carried out as follows: $10 \mathrm{~s}$ at $95^{\circ} \mathrm{C}$ for initial denaturation; 40 cycles of $15 \mathrm{~s}$ at $95^{\circ} \mathrm{C}, 1 \mathrm{~min}$ at $56^{\circ} \mathrm{C}$.

Sulfate reducing prokaryotes were quantified by SYBR Green I assays using the primer set DSRp2060F (5'-CAACATCGTYCAYACCCAGGG-3') and DSR4R ( $5^{\prime}$-GTGTAGCAGTTACCGCA-3') described by Geets et al.

Table 1

Chemical properties of a Chinese paddy soil under different fertilization treatments

\begin{tabular}{|c|c|c|c|c|c|c|}
\hline \multirow[t]{2}{*}{ Treatment } & \multicolumn{2}{|l|}{$\mathrm{pH}\left(\mathrm{H}_{2} \mathrm{O}\right)$} & \multicolumn{2}{|c|}{ Organic matter $\left(\mathrm{g} \mathrm{kg}^{-1}\right)$} & \multicolumn{2}{|c|}{ Sulfate concentration $(\mu \mathrm{M})$} \\
\hline & Winter & $\overline{\text { Summer* }}$ & Winter & Summer & Winter & Summer \\
\hline$\overline{\mathrm{CT}^{\mathrm{a}}}$ & $4.8 \pm 0.1 a^{b}$ & $4.9 \pm 0.0 \mathrm{a}$ & $25.9 \pm 0.9 a$ & $29.2 \pm 1.1 \mathrm{a}$ & $99 \pm 28 a$ & $87 \pm 17 a$ \\
\hline $\mathrm{N}$ & $4.8 \pm 0.0 \mathrm{a}$ & $5.0 \pm 0.0 a$ & $26.0 \pm 5.1 a$ & $30.2 \pm 5.1 a$ & $78 \pm 14 a$ & $66 \pm 6 a$ \\
\hline NP & $4.9 \pm 0.1 b$ & $5.0 \pm 0.0 a$ & $26.3 \pm 6.8 a$ & $31.0 \pm 7.5 a$ & $89 \pm 20 a$ & $114 \pm 5 b$ \\
\hline NK & $5.0 \pm 0.0 c$ & $5.0 \pm 0.1 a$ & $26.2 \pm 4.7 a$ & $30.5 \pm 5.0 a$ & $90 \pm 13 a$ & $80 \pm 13 a$ \\
\hline NPK & $4.7 \pm 0.0 \mathrm{~d}$ & $4.8 \pm 0.0 \mathrm{~b}$ & $31.2 \pm 1.4 a$ & $33.1 \pm 7.5 a$ & $168 \pm 23 b$ & $159 \pm 18 c$ \\
\hline
\end{tabular}

*Values differ at $P<0.05$ between winter and summer.

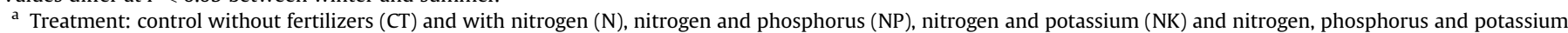
combined (NPK).

b Mean \pm SD. Values within the same column followed by the same letter do not differ at $P<0.05$. 
(2006). The $25-\mu \mathrm{l}$ reaction mixture consisted of $12.5 \mu \mathrm{l}$ of $\mathrm{SYBR}^{\circledR}$ Premix Ex Taq ${ }^{\mathrm{TM}}$ (Takara Biotechnology, Japan), $1 \mu \mathrm{l}$ of BSA $\left(25 \mathrm{mg}^{-1} \mathrm{l}^{-1}\right), 0.5 \mu \mathrm{l}$ of each primer $(10 \mu \mathrm{M})$ and $2 \mu \mathrm{l}$ of 50 -fold diluted extracted DNA (1-5 ng) as template. Quantitative PCR was carried out as follows: 2 min at $95^{\circ} \mathrm{C}$ for initial denaturation; 40 cycles of 10 s at $95^{\circ} \mathrm{C}, 30$ s at $50^{\circ} \mathrm{C}$, and 30 s at $72{ }^{\circ} \mathrm{C}$.

For the preparation of bacterial 16S rRNA gene and $d s r A B$ gene standards, full-length $16 \mathrm{~S}$ rRNA gene and dsrAB gene were PCRamplified from extracted DNA with the primers 27F/1492R (Lane, 1991) and DSRp2060F/DSR4R, respectively, and then cloned into the pGEM-T Easy Vector (Promega, USA). Plasmids from the proper insert clones of the each target gene were extracted and used as standards for the calibration curve. SYBR Green I assays were always performed with a melting curve analysis which was used to check the specificity of the products. Triplicates for standard and unknown template were performed on a single plate. The results were analyzed using the $\mathrm{iQ}^{\mathrm{TM}} 5$ software (Bio-Rad, USA). The amplification efficiency was calculated based on the slope of the standard curve with the formula $E=10^{-1 / \text { slope }} \times 100 \%$. Copy numbers were log-transformed to normalize the values prior to statistical analysis and ANOVA analysis was used to check quantitative differences between treatments and seasons under significant differences $P<0.05$.

\subsection{Construction of the dsrAB Gene Clone Library and RFLP Analysis}

The $d s r A B$ genes were PCR-amplified with the DSR1F ( $5^{\prime}-\mathrm{AC}[\mathrm{C} /$ G]CACTGGAAGCACG-3', positions 421-436 of Desulfovibrio vulgaris, GenBank accession no. U16723) and DSR4R (5'-GTGTAGCAGTTACCGCA-3', positions 2347-2363 of Desulfovibrio vulgaris, GenBank accession no. U16723) primer set as previously described (Wagner et al., 1998), which produces a 1.9-kb fragment. Amplification was performed in a $50 \mu \mathrm{l}$ final volume with $5 \mu \mathrm{l} 10 \times$ PCR buffer, $3 \mu \mathrm{l} 25 \mathrm{mM} \mathrm{MgCl}_{2}, 4 \mu \mathrm{l} 2.5 \mathrm{mM}$ dNTPs, $0.5 \mu \mathrm{l}$ Taq polymerase

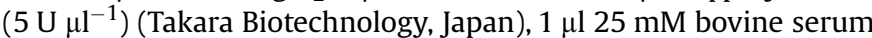
albumin (BSA), $1.5 \mu \mathrm{l}$ of each primer (final concentration of $0.3 \mu \mathrm{M}$ ), and $2 \mu \mathrm{l}$ of template DNA (1-10 $\mathrm{ng}$ ). The amplification reaction was conducted as follows: $5 \mathrm{~min}$ at $94{ }^{\circ} \mathrm{C}, 35$ cycles of $94{ }^{\circ} \mathrm{C}$ for $45 \mathrm{~s}$, $58{ }^{\circ} \mathrm{C}$ for $45 \mathrm{~s}$ and $72{ }^{\circ} \mathrm{C}$ for $2 \mathrm{~min}$, and a final extension at $72{ }^{\circ} \mathrm{C}$ for $10 \mathrm{~min}$. The PCR products were confirmed by a $1 \%$ agarose gel electrophoresis and purified with Wizard ${ }^{\circledR}$ SV Gel and PCR CleanUp System (Promega, USA). Fifteen $d s r A B$ clone libraries of the purified PCR products of all the replicates of five treatments from summer were constructed using the $\mathrm{pGEM}^{\circledR}$-T Easy Vector Systems (Promega, USA), and E. coli JM109 was transformed as competent host cells (Takara Biotechnology, Japan) according to the manufacture's instructions. Approximately 100 white colonies were randomly selected from each library. Clones were screened for inserts of the expected size with the vector-specific primers T7 and SP6. For restriction fragment length polymorphism (RFLP) and sequencing, the insert fragments were digested with restriction endonuclease Hha I (Takara Biotechnology, Japan) and incubated at $37^{\circ} \mathrm{C}$ for $2 \mathrm{~h}$. The restricted fragments were separated by gel electrophoresis in 3\% agarose with ethidium bromide and observed under UV illumination. The fingerprint images of the RFLP band types in each replicate of five fertilization treatments were analyzed by the software Quantity One (Bio-Rad, USA) and grouped based on different band patterns. Evaluation of the clone libraries was performed by a rarefaction analysis using software aRarefactWin Version 1.3 (Steven Holland, Stratigraphy Lab, University of Georgia [http://www.uga.edu/strata/software/Software.html]). Diversity of each clone library based on the RFLP fingerprints was calculated by the Shannon Diversity Index $\left(H^{\prime}\right)$ and statistically analyzed using ANOVA.

\subsection{Sequencing and Phylogenetic Analysis}

The clones of unique RFLP band types in each library were selected. The part encoding the $\beta$-subunit of the dissimilatory sulfate reductase (amino acid sequences of DsrB were used subsequently) was sequenced on the $\mathrm{ABI} 3700$ sequencer (Applied Biosystems, USA). The sequences were deposited in GenBank database under the following accession numbers: EU258766EU258889. After translation into amino acids, homology analysis of the DsrB sequences was performed using the software DNAMAN version 6.0.3.48 (Lynnon Biosoft, USA). Sequences displaying more than $90 \%$ amino acid identity with each other were grouped into the same operational taxonomic units (OTUs). The representative amino acid sequences of each OTU were aligned with the most similar deduced amino acid sequences of SRP retrieved from GenBank/EMBL/DDBJ/PDB database using the software Clustal X 1.83.V (Thompson et al., 1994). For phylogenetic analysis, insertions and deletions were removed using blast alignment filter (indel filter), which resulted in 210 amino acid positions for the $\beta$-subunit. Phylogenetic analysis was performed using MEGA version 4.0 and the neighbor-joining tree was constructed using the Poisson correction model with Bootstrap value of 1000 (Tamura et al., 2007).

\subsection{Statistical Analysis and Sequence Diversity}

There is no consensus on how to define species or genera based on $d s r A B$ sequence similarity. In this study, sequences displaying more than $90 \%$ amino acid identity with each other were considered as an OTU. The coverage $(C)$ for each clone library was calculated using formula $C=1-\left(n_{1} / N\right) \times 100 \%$, where $n_{1}$ is the number of OTU containing only one $d s r A B$ clone and $N$ is the total number of clones analyzed (Singleton et al., 2001). The composition differences of SRP community structure among the five fertilization regimes were statistically analyzed using ANOVA. The similarity of phylogenetic compositions of the libraries were compared using the Sorensen similarity index, $\mathrm{Cs}=2 j /(a+b)$, in which $j$ is the number of OTUs common to both samples and $a$ and $b$ are the numbers of OTUs in libraries A and B, respectively (Magurran, 1988).

\section{Results}

\subsection{Soil Chemical Properties}

There were significant differences $(P<0.05)$ in soil $\mathrm{pH}$ between winter and summer, and between all the treatments (Table 1 ). No significant differences of soil organic matter were observed between different treatments and seasons. Soil sulfate concentration did not vary significantly with season, but significant differences were observed between all the treatments both in winter and summer. The NPK treatment had the highest sulfate concentrations of 168 and $159 \mu \mathrm{M}$ in winter and summer, respectively. The lowest sulfate concentrations of 78 and $66 \mu \mathrm{M}$ were recorded in the $\mathrm{N}$ treatments of both seasons.

\subsection{Abundance of Bacteria in the Paddy Soil}

No significant differences $(P<0.05)$ were detected in the bacterial abundance, determined as 16S rRNA gene copy numbers, among the five fertilization treatments in both winter and summer (Fig. 1A). The mean bacterial abundance was $7.26 \times 10^{9}{\text { copies } g^{-1}}^{-1}$ dry soil in winter and $1.27 \times 10^{10}$ copies $\mathrm{g}^{-1}$ dry soil in summer. Bacterial abundance was approximately one order of magnitude lower in winter than in summer. 

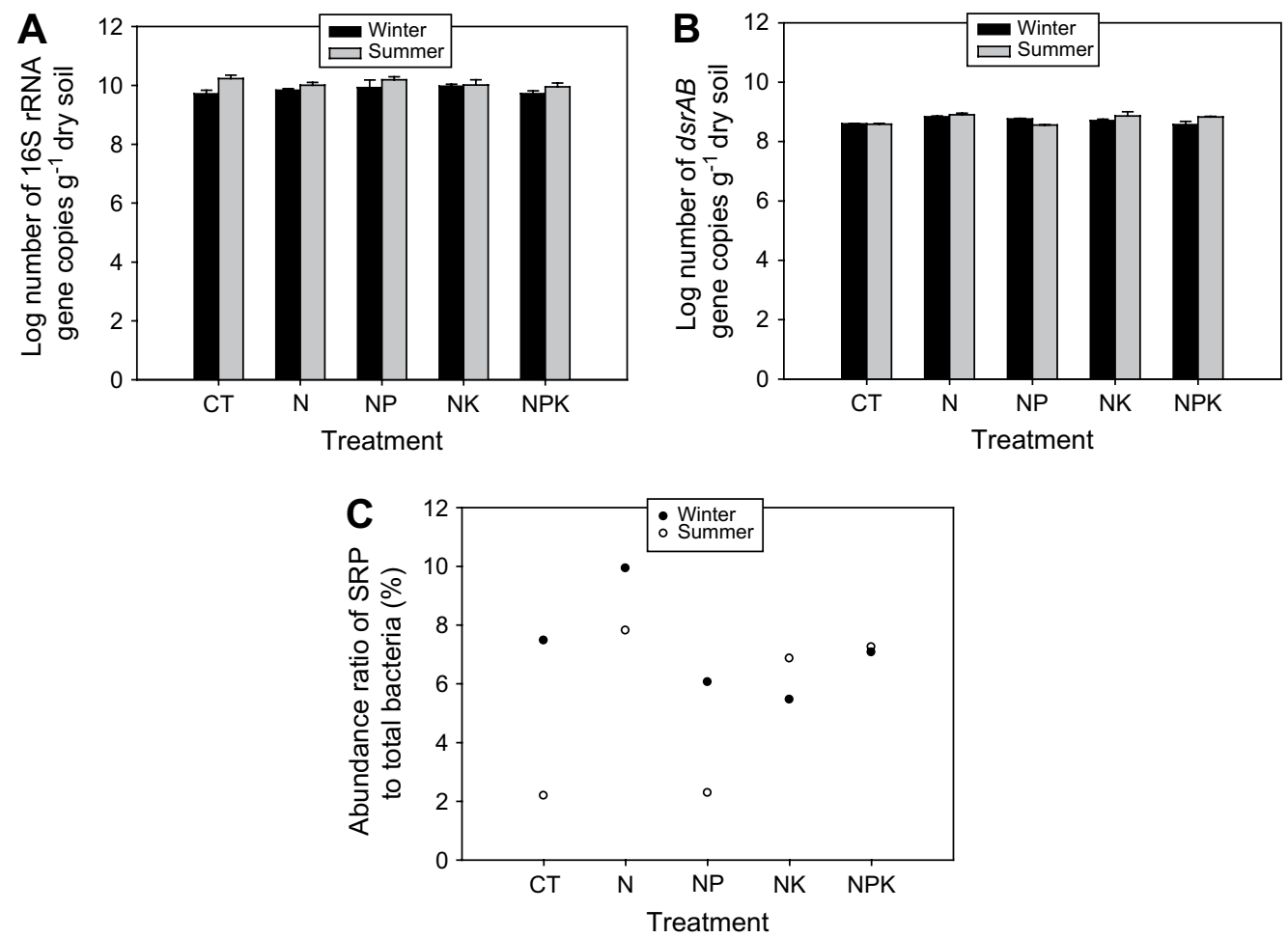

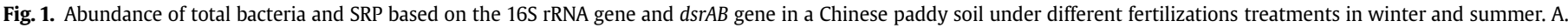
Total bacteria copy numbers. B. Total SRP copy numbers. C. SRP copy numbers as a proportion of total Bacteria.

\subsection{Abundance of SRP in the Paddy Soil}

No significant differences $(P<0.05)$ in the SRP abundance were detected among the five treatments in both winter and summer (Fig. 1B). The average $d s r A B$ gene copy numbers of the SRP was

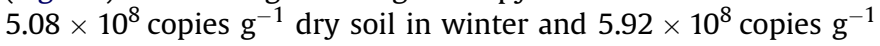
dry soil in summer. There was no significant difference $(P<0.05)$ in the $d s r A B$ gene copy numbers between winter and summer.

By assuming 3.6 copies of 16S rRNA gene per cell (Klappenbach et al., 2001) and only one copy of $d s r A B$ gene per SRP cell (Klein et al., 2001), quantitative data of copy numbers were expressed as a number of cells per gram dry soil. The proportion of sulfate reducer to the total bacterial community was calculated (Fig. 1C). The proportion ranged from 5 to $10 \%$ in winter and 2 to $8 \%$ in summer among CT, N, NP, NK and NPK treatments. The proportions in the NPK treatments for both winter and summer were similar, while ratios in $\mathrm{CT}, \mathrm{N}$, NP treatments were much higher in winter than in summer.

\subsection{RFLP Analysis of the dsrAB Clone Libraries}

Each of the $d s r A B$ clone libraries was clustered into 22-25 RFLP groups based on the band patterns (Table 2). Clone libraries were statistically evaluated by rarefaction analysis in which the expected number of different RFLP groups vs. the number of clones in the library was calculated (Wagner et al., 2005; Leloup et al., 2007). Rarefaction curves tended to approach the saturation plateau (Fig. 2), indicating that 100 clones used in each of libraries screening could well cover the diversity of the $d s r A B$ genes. Shannon-Weaver Diversity Index $\left(H^{\prime}\right)$ was used to evaluate the diversity of each clone library, and no significant differences were observed between different fertilization treatments (Table 2).

\subsection{Phylogenetic Analysis of the dsrAB Sequences}

To further characterize the $d s r A B$ RFLP groups, a total of 310 clones representing different RFLP patterns in different fertilization treatments from summer samples were partially sequenced, yielding deduced sequences of approximately 210 amino acids of DsrB. Blast comparisons of nucleotide sequences in the NCBI database yielded 284 unique sequences representative of $d s r A B$ genes, which were then grouped into 64 OTUs, termed AAOTUs based on $90 \%$ threshold of amino acid (AA) identity. A phylogenetic analysis of the deduced DsrB sequences and 42 reference sequences retrieved from the NCBI database yielded 8 distinct clusters (Fig. 3). Clusters were defined on the basis of bootstrap values and interOTU DsrB identities, in which OTUs with bootstrap values either $>50 \%$ or inter-OTU DsrB identities $>70 \%$ were categorized in different clusters. Although some clusters contained sequences of known cultured SRP, the most abundant sequences within clone

Table 2

RFLP analysis of clone libraries obtained from a Chinese paddy soil following five fertilization regimes

\begin{tabular}{lcllc}
\hline Treatment & $\begin{array}{l}\text { Number } \\
\text { of clones }^{\mathrm{a}}\end{array}$ & $\begin{array}{l}\text { RFLP } \\
\text { patterns }^{\mathrm{a}}\end{array}$ & $\begin{array}{l}\text { Shannon-Weaver } \\
\text { Diversity Index }\left(H^{\prime}\right)\end{array}$ & $\begin{array}{l}\text { dsrAB } \\
\text { sequences }\end{array}$ \\
\hline $\mathrm{CT}^{\mathrm{b}}$ & 99 & 25 & $3.04 \pm 0.08^{\mathrm{c}}$ & 39 \\
$\mathrm{~N}$ & 89 & 22 & $2.93 \pm 0.10^{\mathrm{c}}$ & 64 \\
$\mathrm{NP}$ & 98 & 25 & $3.03 \pm 0.12^{\mathrm{c}}$ & 58 \\
$\mathrm{NK}$ & 100 & 23 & $2.94 \pm 0.10^{\mathrm{c}}$ & 60 \\
$\mathrm{NPK}$ & 98 & 22 & $2.85 \pm 0.19^{\mathrm{c}}$ & 63 \\
Total & 484 & & & 284 \\
\hline
\end{tabular}

${ }^{a}$ Mean value of three replicates of each fertilization treatment.

b Treatment: Control without fertilizers (CT) and with N, NP, NK and NPK.

${ }^{c}$ Values within the same column followed by the same letter do not differ at $P<0.05$. 


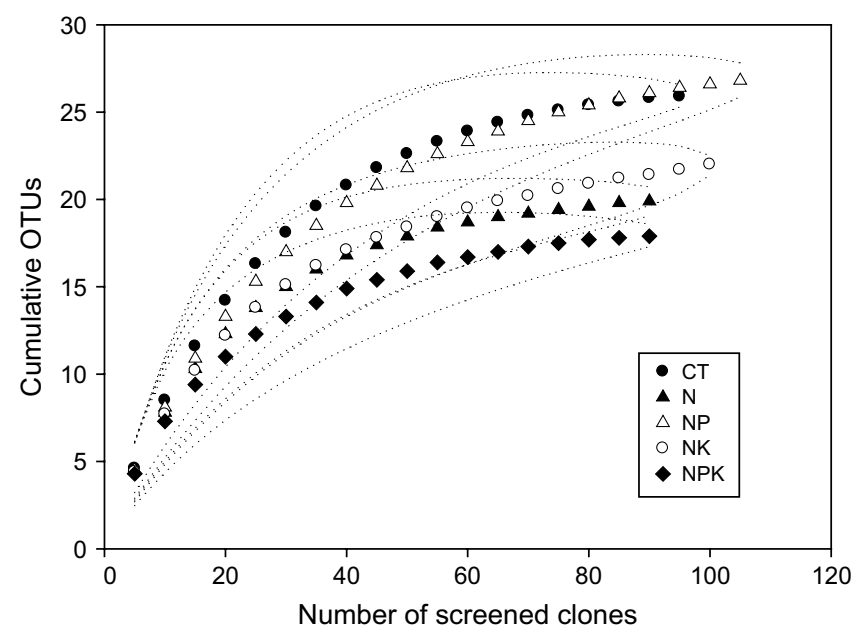

Fig. 2. Rarefaction analysis of the $d s r A B$ clones obtained from the five fertilization treatments of a Chinese paddy soil using software aRarefactWin Version 1.3. Dashed lines represent $99 \%$ confidence intervals.

libraries were found in DSR cluster- 5 and DSR cluster-8, affiliated to unknown uncultured SRP (59.2\% of the total clone numbers, Table 3 ).

Seventy nine clones of AAOTU-1-AAOTU-5 and AAOTU-39AAOTU-63 were included in the DSR cluster-7, related to the genera Desulfitobacterium, Desulfosporosinus, Desulfotomaculum, Desulfitibacter and Pelotomaculum within the Clostridia. This cluster accounted for $27.8 \%$ of the total clones. DSR cluster-1, DSR cluster- 2 and DSR cluster- 3 belonged to the Deltaproteobacteria in the Proteobacteria ( $11.6 \%$ of the total clones, Table 3 ). DSR cluster- 1 included clone OTUs AAOTU-27-AAOTU-34. It was closely affiliated to the family Syntrophobacteraceae, composed of genera Syntrophobacter, Desulforhabdus, Desulfovirga, Thermodesulfohabdus, and Desulfacinum. DSR cluster-2 included clones from OTUs AAOTU-10 to AAOTU-14, AAOTU-25 and AAOTO-26, and was closely related to the family Syntrophaceae, composed of the genera Desulfomonile and Desulfobacca. DSR cluster-3 included clone OTUs AAOTU-35, OTUs AAOTU-36 and OTUs AAOTU-37, which were related to the family Desulfobacteraceae. Three OTUs AAOTU-22, AAOTU-23 and AAOTU-24 fell within DSR cluster-6, affiliated to the genus Archaeoglobus. This cluster was the only archaeal SRP in all the clone libraries. Only a single clone OTU AAOTU-38 related to the genus Thermodesulfobacterium was detected.

\subsection{Distribution of SRP Clusters in Different Fertilization Clone Libraries}

The relative abundance of the eight different clusters in the CT, N, NP, NK and NPK clone libraries was calculated (Table 3). Statistical analysis revealed that there was no significant difference $(F=0.116, P<0.05)$ among the five long-term fertilization treatments in their SRP community structure. Three clusters, Syntrophaceae, Clostridia and uncultured SRP-1, were detected in all fertilization treatments. Clones from Syntrophobacteraceae and Desulfobacteraceae were distributed in all the fertilization treatments except CT. Clones from Archaelglobaceae was distributed only in the N, NK and NPK treatments. DSR cluster- 4 related to Thermodesulfobacteriaceae and DSR cluster- 8 of uncultured SRP-2 were detected only in the treatments of NP and NK, respectively. In total, the CT treatment had the least SRP diversity, containing only three clusters.

Using the $90 \%$ amino acid similarity cut-off value, the coverage mean values from three replicates of the five fertilization clone libraries were $85,73,79,62$ and $76 \%$ for CT, N, NP, NK and NPK treatments, respectively. The $\mathrm{NK}$ treatment had the lowest coverage values indicating that the $d s r A B$ sequences from the NK treatment was the most diverse. The Sorensen similarity index was used to identify the similarity of community composition between the treatments. The values ranged from 28 to $49 \%$. The CT and N treatment libraries had the highest Sorensen similarity index, indicating that they had the most similar composition (Table 4). The NK treatment had the lower values of $28,29,33$, and 35\% compared with NPK, CT, NP, and N treatments, and thus it was the most different one with the other treatments.

\section{Discussion}

\subsection{Abundance of SRP in the Paddy Soil}

Real-time PCR is considered a highly sensitive method for the quantification of microbial organism in environmental samples (Smith et al., 2006) and now used in this study to examine the SRP abundance. Sulfate concentrations in the paddy soil studied here ranged from 66 to $168 \mu \mathrm{M}$, which is comparable with previous studies of 30-300 $\mu \mathrm{M}$ in the upper $10 \mathrm{~cm}$ in paddy soils (Wind and Conrad, 1995, 1997). Sulfate reducing prokaryotes can survive well in lower sulfate concentrations, such as in the freshwater and paddy soil environments (Barton and Tomei, 1995; Habicht et al., 2005). Here, quantification of SRP was performed using the $\beta$ subunit of the key functional gene, dissimilatory (bi)sulfite reductase $(d s r A B)$ and abundance ranged from $3.60 \times 10^{8}$ to $8.02 \times 10^{8}$ copies $g^{-1}$ dry soil (Klein et al., 2001). Similar target SRP numbers have been observed in paddy soil and other freshwater environments or marine sediments environments. For example, by using primer specific for the Gram-negative SRP, $2-4 \times 10^{8}$ copies $\mathrm{g}^{-1}$ dry soil was detected in rice field bulk soil (Stubner, 2004). SRP abundances ranging from 0.2 to $5.7 \times 10^{8}$ copies $\mathrm{ml}^{-1}$ have been observed in estuarine sediment, using competitive PCR (Kondo et al., 2004), and $10^{8} d s r A B$ gene copies $\mathrm{cm}^{-3}$ in upper $10 \mathrm{~cm}$ of a marine sediment (Schippers and Neretin, 2006). The observed proportions of SRP to total bacteria, 5-10\% in winter and $2-8 \%$ in summer, were also similar to previously reported estimates in marine near-surface sediments, which ranged from 2 to $10 \%$ (Ravensschlag et al., 2000; Castro et al., 2002; Leloup et al., 2007). Freshwater habitats with low sulfate concentration, such as paddy soil, therefore show similar relative abundance of SRP to marine sediments, in which organic matter dissimilation is dominated by sulfate reduction. However, it remains uncertain whether these SRP survive as sulfate reducers or they grow through fermentation. SRP relative abundance in Italian paddy soils was also similar to values obtained in this study, with Desulfobacteriaceae identified as the predominant Gram-negative group in rice bulk and rhizosphere soil, accounting for 2-3\% of the rRNA content using rRNA dot blot hybridization (Scheid and Stubner, 2001). Desulfotomaculum lineage 1 was the main Gram-positive group in a paddy soil and had abundance of 2 and $0.5 \%$ of the total bacteria in the rice bulk soil and the rice root using the real-time PCR (Stubner, 2002) but that of 0.55 and $1 \%$ using rRNA dot blot hybridization (Stubner and Meuser, 2000)

\subsection{Composition and Diversity of the SRP}

Three major groups of $d s r A B$ sequences were found in this study, belonging to uncultured SRP clusters, Clostridia and Deltaproteobacteria. Most interestingly, the majority of $d s r A B$ gene sequences fell within novel uncultured SRP in this study and the group of uncultured SRP-1 (58.8\%) was estimated as a sister group to Deltaproteobacteria from the phylogenetic position of uncultured 


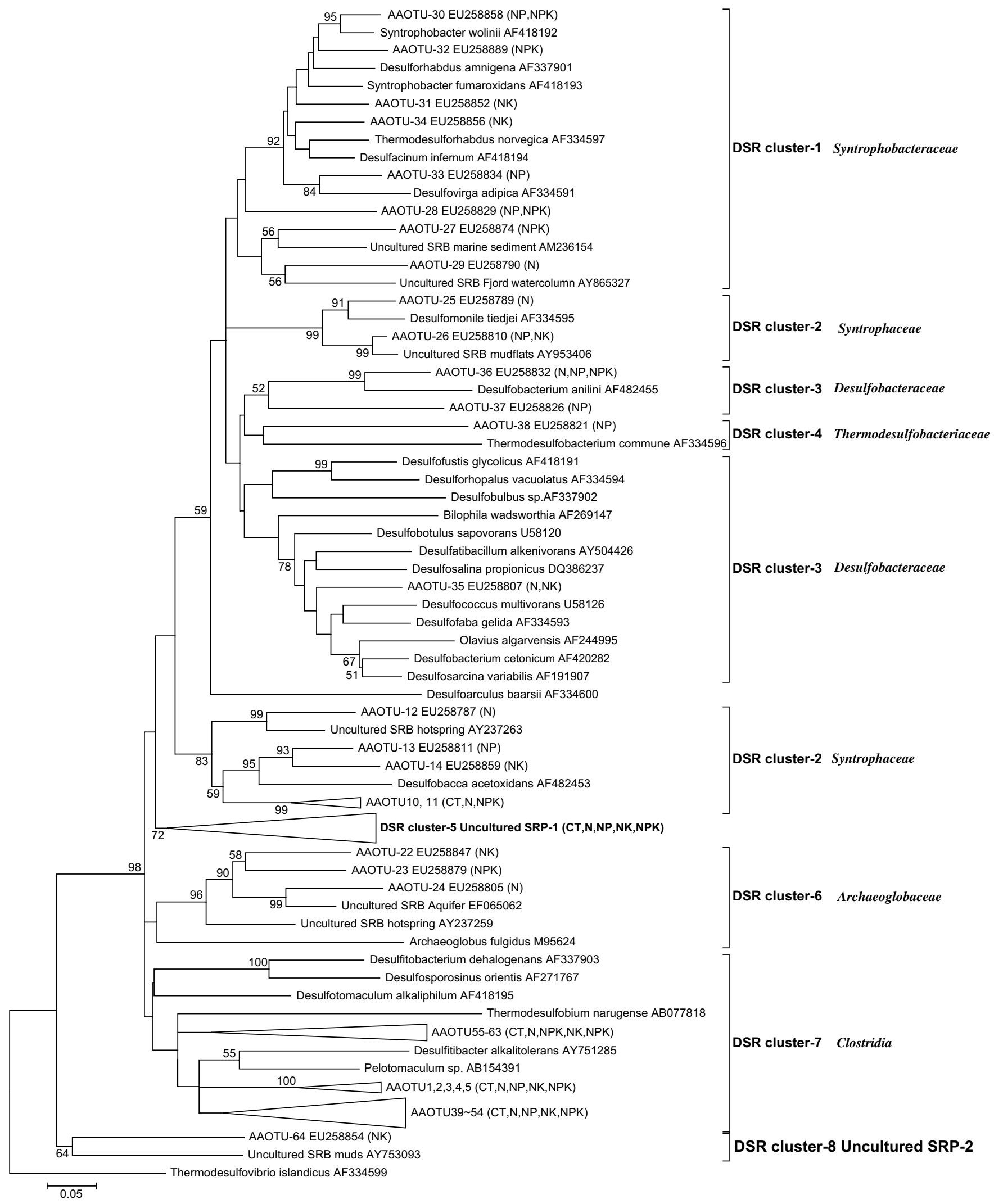

Fig. 3. Phylogenetic tree of protein sequences of the dissimilatory (bi)sulfite reductase $\beta$-subunit ( 210 amino acids of DsrB) retrieved from CT, N, NP, NK and NPK fertilization treatments of a Chinese paddy soil and selected sequences from known and uncultured environmental SRP. The tree was constructed using neighbor-joining algorithm. The scale bar shows 0.01 estimated sequence divergence. 
Table 3

Distribution of the dsrAB sequences in different clusters under CT, N, NP, NK, and NPK fertilization regimes of a Chinese paddy soil

\begin{tabular}{|c|c|c|c|c|c|c|c|c|}
\hline Treatment & $\begin{array}{l}\text { Syntrophobacteraceae } \\
(\%)^{\mathrm{a}}\end{array}$ & $\begin{array}{l}\text { Syntrophaceae } \\
(\%)\end{array}$ & $\begin{array}{l}\text { Desulfobacteraceae } \\
(\%)\end{array}$ & $\begin{array}{l}\text { Thermodesulfobacteriaceae } \\
\text { (\%) }\end{array}$ & $\begin{array}{l}\text { Clostridia } \\
(\%)\end{array}$ & $\begin{array}{l}\text { Archaeoglobaceae } \\
(\%)\end{array}$ & $\begin{array}{l}\text { Uncultured SRP-1 } \\
(\%)\end{array}$ & $\begin{array}{l}\text { Uncultured SRP-2 } \\
(\%)\end{array}$ \\
\hline$\overline{\mathrm{CT}^{\mathrm{b}}}$ & 0 & 2.6 & 0 & 0 & 23.1 & 0 & 74.3 & 0 \\
\hline $\mathrm{N}$ & 1.6 & 6.2 & 3.1 & 0 & 39.1 & 1.6 & 48.4 & 0 \\
\hline NP & 5.2 & 6.9 & 5.2 & 1.7 & 36.2 & 0 & 44.8 & 0 \\
\hline NK & 5.0 & 3.3 & 3.3 & 0 & 21.7 & 1.7 & 63.3 & 1.7 \\
\hline NPK & 4.8 & 6.3 & 1.6 & 0 & 17.4 & 1.6 & 68.3 & 0 \\
\hline Total & 3.5 & 5.3 & 2.8 & 0.4 & 27.8 & 1.1 & 58.8 & 0.4 \\
\hline
\end{tabular}

Three families of Sytrophotacteraceae, Syntrophaceae and Desulfobacteraceae belong to Deltaproteobacteria.

a Proportion of sequences is calculated as ratio of analyzed sequences affiliated with different clusters to the total sequences number in clone library.

b Treatments as described in Table 1.

SRP-1 in the vicinity of Deltaproteobacteria. The most abundant sequences could not be related to any known cultured SRP, but were most closely related to environmental sequences retrieved from aquifer, fen, hot spring, mud, mudflat and marine sediment environments. The group of uncultured SRP dominated the SRP community and may play an important role in the paddy soil.

The $d s r A B$ sequences of Deltaproteobacteria fell mainly in Desulfobacteraceae, Syntrophobacteraceae and Syntrophaceae and no $d s r A B$ gene sequence affiliated within Desulfovibrionaceae was found, despite their wide distribution and predominance in rice roots (Ouattara and Jacq, 1992). The reason for the absence of Desulfovibrionaceae in this paddy soil could be due to that these microorganisms may only be present in very low numbers in the paddy soil. It was speculated that the relative rRNA content of the Desulfobacteriaceae on rice roots was much higher than that of the Desulfovibrionaceae using 16S rRNA dot blot hybridization (Scheid and Stubner, 2001), and Desulfobacteriaceae were the predominant SRP group in rice field bulk and rhizosphere soil (Stubner, 2004). The relatively high abundance of clones related to Syntrophobacteraceae and Syntrophaceae is interesting as they are often found in the marine sediments with high sulfate concentration and salinity (Leloup et al., 2007). Syntrophobacter strains are reported to possess diverse metabolic capabilities such as energyconserving metabolism of requiring less sulfate, which may be a preferred feature in paddy soils under low sulfate concentration (Wind and Conrad, 1995; Oude Elferink et al., 1995).

Gram-positive sulfate reducing bacteria have been reported as an important group in rice field soil (Stubner and Meuser, 2000) and $27.8 \%$ of total clones in this study were affiliated with the Clostridia, most of which were related to Desulfotomaculum, Desulfobacterium, Desulfosporosinus, Desulfitibacter and Pelotomaculum. The $d s r A B$ sequences of Gram-positive bacteria did not form a monophyletic lineage, as observed by Klein et al. (2001) using the $16 \mathrm{~S}$ rRNA gene as phylogenetic marker, suggesting significant lateral gene transfer. The composition of Gram-positive in this study is consistent with previous findings that Clostridia represent an important bacterial group in anoxic bulk soil (Hengstmann et al., 1999; Ludemann et al., 2000). Leloup et al. (2005) observed that $17.5 \%$ of the total clones of freshwater mudflat were closely related

\section{Table 4}

Comparison of the compositions of libraries between different treatments of a Chinese paddy soil

\begin{tabular}{lllll}
\hline & \multicolumn{4}{l}{ Sorensen similarity index (\%) for the fertilization library } \\
\cline { 2 - 5 } & $\mathrm{N}^{\mathrm{a}}$ & $\mathrm{NP}$ & $\mathrm{NK}$ & $\mathrm{NPK}$ \\
\hline $\mathrm{CT}^{\mathrm{a}}$ & 49 & 41 & 29 & 46 \\
$\mathrm{~N}$ & & 40 & 35 & 43 \\
$\mathrm{NP}$ & & 33 & 37 \\
$\mathrm{NK}$ & & & 28 \\
\hline
\end{tabular}

a Treatments as described in Table 1. to the $d s r A B$ sequences of Gram-positive Desulfotomaculum, Desulfosporosinus and Desulfitobacterium. These microorganisms prefer to live in aquifers and freshwater sediments with low sulfate and salinity concentrations (Stackebrandt et al., 1997; Detmers et al., 2004), and may be adapted to low nutrient environments because of their capacity for sporulation (Sass et al., 1997).

\subsection{Effects of Different Fertilization Treatments on Soil SRP Community Structure}

Soil SRP community shifts could be driven by different environment factors, such as phosphorus gradient, depth gradient, $\mathrm{O}_{2}$ gradient, dimensional difference (e.g., rhizosphere and bulk soil) (Sass et al., 1997; Wind et al., 1999; Castro et al., 2002; Schmalenberger et al., 2007). However, the effect of fertilization regimes on SRP community structure was seldom observed. In this study, there was no significant difference in the paddy soil SRP community structure under the five long-term fertilization practices, indicating that the fertilization practice has no significant effect on the paddy soil SRP community structure. The NPK treatment had significant higher sulfate concentration than the other treatments. We speculate that the sulfate concentration is not a limiting factor for the SRP community structure. It was also noticed that the soil $\mathrm{pH}$ could be divided into four significantly different groups among the five fertilization treatments under $P<0.05$ significant level. It indicated that the soil $\mathrm{pH}$ changed from 4.7 to 5.0 had no significant effect on the SRP community. It is interesting to note that some clusters such as Archaelglobaceae, Thermodesulfobacteriaceae and DSR cluster-8 appeared in certain fertilization treatments, but they accounted for a minor proportion to the total clone library and did not significantly change the SRP community structure. Therefore, the long-term fertilization treatments did not result in significant changes in the soil SRP community structure.

\section{Conclusions}

Sulfate concentrations in the paddy soil ranged from 66 to $168 \mu \mathrm{M}$, which were much lower than the marine environment. There were similar abundances for SRP in the paddy soil with different fertilization regimes, ranging from $3 \sim 8 \times 10^{8}$ copies $^{-1}$ dry soil. The proportion of SRP to total bacteria ranged from $5 \sim 10 \%$ in winter and $2 \sim 8 \%$ in summer. It implied that these microorganisms might have a greater role in the paddy soil than previously anticipated. Phylogenetic analysis of all 15 clone libraries under different fertilization regimes showed that there was no significant change in the soil SRP community structure among the treatments, and uncultured SRP followed by Clostridia and Deltaproteobacteria were the dominant groups in the paddy soil. Further studies that whether these unidentified SRP are active and which metabolism strategies they employ to thrive in paddy soils are needed. Moreover, detailed correlations between controlling factors and the changes of 
abundances and compositions of SRP are also needed to better understand their functions in paddy soils.

\section{Acknowledgements}

This work was supported by the Chinese Academy of Sciences (KZCX1-YW-0603, KZCX2-YW-408), the Ministry of Science and Technology (2005CB121104) and the Natural Science Foundation of China (40701087, 40871129).

\section{References}

Achtnich, C., Schuhmann, A., Wind, T., Conrad, R., 1995. Role of interspecies $\mathrm{H}_{2}$ transfer to sulfate and ferric iron-reducing bacteria in acetate consumption in anoxic paddy soil. FEMS Microbiology Ecology 16, 61-70.

Barton, L.L., Tomei, F.A., 1995. Characteristics and activities of sulfate-reducing bacteria. In: Barton, L.L. (Ed.), Sulfate-reducing bacteria. Peplum Press, New York, NY, USA, pp. 1-179.

Castro, H.F., Williams, N.H., Ogram, A., 2000. Phylogeny of sulfate-reducing bacteria. FEMS Microbiology Ecology 31, 1-9.

Castro, H., Reddy, K.R., Ogram, A., 2002. Composition and function of sulfatereducing prokaryotes in eutrophic and pristine areas of the Florida Everglades. Applied and Environmental Microbiology 68, 6129-6137.

Detmers, J., Strauss, H., Bergmann, U., Knittel, K., Kuever, J., 2004. FISH shows that Desulfotomaculum spp. are the dominating sulfate-reducing bacteria in a pristine aquifer. Microbial Ecology 47, 236-242.

Dhillon, A., Teske, A., Dillon, J., Stahl, D.A., Sogin, M.L., 2003. Molecular characterization of sulfate-reducing bacteria in the Guaymas basin. Applied and Environmental Microbiology 69, 2765-2772.

Elshahed, M.S., Senko, J.M., Najar, F.Z., Kenton, S.M., Roe, B.A., Dewers, T.A., Spear, J.R., Krumholz, L.R., 2003. Bacterial diversity and sulfur cycling in a mesophilic sulfide-rich spring. Applied and Environmental Microbiology 69, 5609-5621.

Ge, Y., Zhang, J.B., Zhang, L.M., Yang, M., He, J.Z., 2008. Long-term fertilization regimes affect bacterial community structure and diversity of an agricultural soil in northern China. Journal of Soils and Sediments 8, 43-50.

Geets, J., Borremans, B., Diels, L., Springael, D., Vangronsveld, J., Lelie, D.V.D., Vanbroekhoven, K., 2006. dsrB gene-based DGGE for community and diversity surveys of sulfate-reducing bacteria. Journal of Microbiological Methods 66, 194-205.

Gilmour, C.C., Riedel, G.S., Ederington, M.C., Bell, J.T., Benoit, J.M., Gill, G.A., Stordal, M.C., 1998. Methylmercury concentrations and production rates across a trophic gradient in the northern Everglades. Biogeochemistry 40, 327-345.

Habicht, K.S., Salling, L., Thamdrup, B., Canfield, D., 2005. Effect of low sulfate concentrations on lactate oxidation and isotope fraction during sulfate reduction by Archaeoglobus fulgidus strain Z. Applied and Environmental Microbiology 71, 3770-3777.

He, J.Z., Shen, J.P., Zhang, L.M., Zhu, Y.G., Zheng, Y.M., Xu, M.G., Di, H.J., 2007. Quantification analysis of the abundance and composition of ammonia-oxidizing bacteria and ammonia-oxidizing archaea of a Chinese upland red soil under longterm fertilization practices. Environmental Microbiology 9, 2364-2374.

He, J.Z., Zheng, Y., Chen, C.R., He, Y.Q., Zhang, L.M., 2008. Microbial composition and diversity of an upland red soil under long-term fertilization treatments as revealed by culture-dependent and culture-independent approaches. Journal of Soils and Sediments 8, 349-358.

Hengstmann, U., Chin, K.J., Janssen, P.H., Liesack, W., 1999. Comparative phylogenetic assignment of environmental sequences of genes encoding 16S rRNA and numerically abundant culturable bacteria from an anoxic rice paddy soil. Applied and Environmental Microbiology 65, 5050-5058.

Jorgensen, B.B., 1982. Mineralization of organic-matter in the sea bed: the role of sulfate reduction. Nature 296, 643-645.

Klappenbach, J.L., Saxman, P.H., Cole, J.R., Schmidt, T.M., 2001. rrndb: the ribosomal RNA operon copy number database. Nucleic Acids Research 29, 181-184.

Klein, M., Friedrich, M., Roger, A.J., Hugenholtz, P., Fishbain, S., Abicht, H., Blackall, L.L., Stahl, D.A., Wagner, M., 2001. Multiple lateral transfers of dissimilatory sulfite reductase genes between major lineages of sulfatereducing prokaryotes. Applied and Environmental Microbiology 67, 6028-6035.

Kondo, R., Nedwell, D.B., Purdy, K.J., Silva, S.Q., 2004. Detection and enumeration of sulphate-reducing bacteria in estuarine sediments by competitive PCR. Geomicrobiology Journal 21, 145-157.

Lane, D.J., 1991. 16S/23S rRNA sequencing. In: Stackebrandt, E., Goodfellow, M. (Eds.), Nucleic acid techniques in bacterial systematics. John Wiley \& Sons, New York, pp. 115-175.

Leloup, J., Quillet, L., Thierry, B., Petit, F., 2005. Diversity of the dsrAB (dissimilatory sulfite reductase) gene sequences retrieved from two contrasting mudflats of the Seine estuary, France. FEMS Microbiology Ecology 55, 230-238.

Leloup, J., Loy, A., Knab, N.J., Borowski, C., Wagner, M., Jorgensen, B.B., 2007. Diversity and abundance of sulfate-reducing microorganisms in the sulfate and methane zones of a marine sediment, Black Sea. Environmental Microbiology 9, 131-142.
Ludemann, H., Arth, I., Liesack, W., 2000. Spatial changes in the bacterial community structure along a vertical oxygen gradient in flooded paddy soil cores. Applied and Environmental Microbiology 66, 754-762.

Mäder, P., Fließbach, A., Dubois, D., Gunst, L., Fried, P., Niggli, U., 2002. Soil fertility and biodiversity in organic farming. Science 296, 1694-1697.

Magurran, A.E., 1988. Ecological diversity and its measurement. Princeton University Press, Princeton.

Ouattara, A.S., Jacq, V.A., 1992. Characterization of sulfate-reducing bacteria isolated from Senegal rice fields. FEMS Microbiology Ecology 101, 217-228.

Oude Elferink, S.J.W.H., Mass, R.N., Harmsen, H.J.M., Stams, A.J.M., 1995. Desulforhabdus amnigenus gen.nov.sp.nov., a sulfate reducer isolated from anaerobic granular sludge. Archives of Microbiology 164, 119-124.

Ravensschlag, K., Sahm, K., Knoblauch, C., Jorgensen, B.B., Amann, R., 2000. Community structure, cellular rRNA content and activity of sulfate reducing bacteria in marine arctic sediments. Applied and Environmental Microbiology 66, 3592-3602.

Sass, H., Cypionka, H., Babenzien, H.D., 1997. Vertical distribution of sulfatereducing bacteria at the oxic-anoxic interface in sediments of the oligotrophic Lake Stechlin. FEMS Microbiology Ecology 22, 245-255.

Scheid, D., Stubner, S., 2001. Structure and diversity of Gram-negative sulfatereducing bacteria on rice roots. FEMS Microbiology Ecology 36, 175-183.

Schibata, A., Toyota, K., Miyake, K., Katayama, A., 2007. Anaerobic biodegradation of 4-alkylphenols in a paddy soil microcosm supplemented with nitrate. Chemosphere 68, 2096-2103.

Schippers, A., Neretin, L.N., 2006. Quantification of microbial communities in nearsurface and deeply buried marine sediments on the Peru continental margin using real-time PCR. Environmental Microbiology 8, 1251-1260.

Schmalenberger, A., Drake, H.L., Kusel, K., 2007. High unique diversity of sulfatereducing prokaryotes characterized in a depth gradient in an acidic fen. Environmental Microbiology 9, 1317-1328.

Shen, J.P., Zhang, L.M., Zhu, Y.G., Zhang, J.B., He, J.Z., 2008. Abundance and composition of ammonia-oxidizing bacteria and ammonia-oxidizing archaea communities of an alkaline sandy loam. Environmental Microbiology 10,1601-1611.

Singleton, D.R., Furlong, M.A., Rathbu, S.L., Whitman, W.B., 2001. Quantitative comparisons of $16 \mathrm{~S}$ rRNA gene sequence libraries from environmental samples. Applied and Environmental Microbiology 67, 4373-4376.

Smith, C.J., Nedwell, D.B., Dong, L.F., Osborn, A.M., 2006. Evaluation of quantitative polymerase chain reaction based approaches for determining gene copy and gene transcript numbers in environmental samples. Environmental Microbiology 8, 804-815.

Stackebrandt, E., Sproer, C., Rainey, F.A., Burghardt, O.P., Hippe, H., 1997. Phylogenetic analysis of the genus Desulfotomaculum: evidence for the misclassification of Desulfotomaculum guttoideum and description of Desulfotomaculum orientis as Desulfosporosinus orientis gen. nov., comb. nov. International Journal of Systematic and Evolutionary Microbiology 47, 1134-1139.

Stubner, S., 2002. Enumeration of 16S rDNA of Desulfotomaculum lineage 1 in rice field soil by real-time PCR with SybrGreen ${ }^{\mathrm{TM}}$ detection. Journal of Microbiological Methods 50, 155-164.

Stubner, S., 2004. Quantification of Gram-negative sulphate-reducing bacteria in rice field soil by $16 \mathrm{~S}$ rRNA gene-targeted real-time PCR. Journal of Microbiological Methods 57, 219-230.

Stubner, S., Meuser, K., 2000. Detection of Desulfotomaculum in an Italian rice paddy soil by $16 \mathrm{~S}$ ribosomal nucleic acid analysis. FEMS Microbiology Ecology 34, 73-80.

Suzuki, M.T., Taylor, L.T., Delong, E.F., 2000. Quantitative analysis of small-subunit rRNA genes in mixed microbial populations via 5'-nuclease assays. Applied and Environmental Microbiology 66, 4605-4614.

Tamura, K., Dudley, J., Nei, M., Kumar, S., 2007. MEGA4: Molecular Evolutionary Genetics Analysis (MEGA) software version 4.0. Molecular Biology and Evolution 24, 1596-1599.

Thompson, J.D., Higgins, D.G., Gibson, T.J., 1994. CLUSTAL W: improving the sensitivity of progressive multiple sequence alignment through sequence weighting, position-specific gap penalties and weight matrix choice. Nucleic Acids Research 22, 4673-4680.

Wagner, M., Roger, A.J., Flax, J.L., Brusseau, G.A., Stahl, D.A., 1998. Phylogeny of dissimilatory sulfite reductases supports an early origin of sulfate respiration. Journal of Bacteriology 180, 2975-2982.

Wagner, M., Loy, A., Klein, M., Lee, N., Ramsing, N.B., Stahl, D.A., Friedrich, M.W. 2005. Functional marker genes for identification of sulfate-reducing prokaryotes. Methods in Enzymology 397, 469-489.

Walkley, A., Black, I.A., 1934. An examination of the Degtjareff method for determining soil organic matter and a proposed modification of chromic acid titration method. Soil Science 37, 29-38.

Wind, T., Conrad, R., 1995. Sulfur compounds, potential turnover of sulfate and thiosulfate, and numbers of sulfate-reducing bacteria in planted and unplanted paddy soil. FEMS Microbiology Ecology 18, 257-266.

Wind, T., Conrad, R., 1997. Localization of sulfate reduction in planted and unplanted rice soil. Biogeochemistry 37, 253-278.

Wind, T., Stubner, S., Conrad, R., 1999. Sulfate-reducing bacteria in rice field soil and on rice roots. Systematic and Applied Microbiology 22, 269-279.

Yang, S.Y., Yoshida, N., Bata, D., Katayama, A., 2008. Anaerobic biodegradation of biphenyl in various paddy soils and river sediment. Chemosphere 71, 328-336.

Zheng, Y., Zhang, L.M., Zheng, Y.M., Di, H.J., He, J.Z., 2008. Abundances and community composition of methanotrophs in a Chinese paddy soil under long-term fertilization practices. Journal of Soils and Sediments 8, 406-414. 